Pontifícia Universidade Catálica $_{\text {a }}$

Merlin Parra Jimenez

Semantic-based Repository of Agent Components

Dissertation presented to the Programa de Pós-Graduação em Informática of the Departamento de Informática, PUC-Rio as partial fulfillment of the requirements for the degree of Mestre em Informática

Advisor: Carlos José Pereira de Lucena 


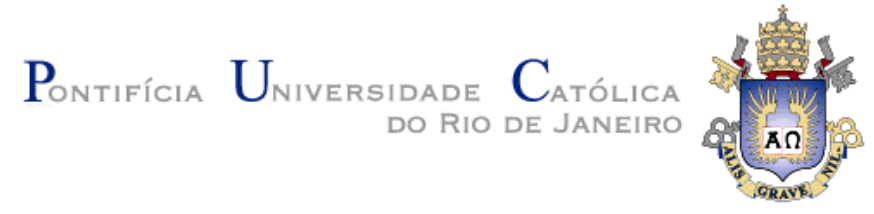

Merlin Parra Jimenez

\section{Semantic-based Repository \\ of Agent Components}

Dissertation presented to the Programa de Pós-Graduação em Informática, of the Departamento de Informática do Centro Técnico Científico da PUC-Rio, as partial fulfillment of the requirements for the degree of Mestre.

Prof. Carlos José Pereira de Lucena

Advisor

Departamento de Informática - PUC-Rio

Prof. Ivan Mathias Filho

Departamento de Informática - PUC-Rio

Prof. Gustavo Robichez de Carvalho

Departamento de Informática - PUC-Rio

Prof. José Eugenio Leal

Coordinator of the Centro Técnico Científico da PUC-Rio

Rio de Janeiro, September $13^{\text {th }}, 2012$ 
All rights reserved

\section{Merlin Parra Jimenez}

Graduated in Computer Science from University of Havana, Cuba in 2006. She is a researcher member of the Software Engineering Laboratory at the Pontifical Catholic University of Rio de Janeiro since 2011. Her main studies are related to the area of software engineering (multi-agent systems and software testing) and semantic web.

Bibliographic data

Jimenez, Merlin Parra

Semantic-based repository of agent components / Merlin Parra Jimenez; advisor: Carlos José Pereira de Lucena - 2012.

94 f.: il. ; $30 \mathrm{~cm}$

Dissertação (mestrado) -Pontifícia Universidade Católica do Rio de Janeiro, Departamento de Informática, 2012.

Inclui bibliografia

1. Informática - Dissertações. 2. Reuso de agentes. 3. Componentes baseadas em agentes. 4. Artefatos orientados a agentes. 5. Repositório de agentes. 6. Recuperação de informação baseada em semântica. 7. Engenharia de software orientada a agentes. I. Lucena, Carlos José Pereira de. II Pontifícia Universidade Católica do Rio de Janeiro. Departamento de Informática. III. Título. 
To the memory of my mom, grandma and aunt Guille, who would be very proud of me and had wanted to enjoy this special moment.

To my aunt Ileana and extended family for the role in my life and education throughout the years.

To Charles for inspiring me to persevere. 


\section{Acknowledgements}

I would like to extend my sincere gratitude to my family, friends, professors and colleagues, during the several months I worked on this thesis, helped me immensely. Without their guidance, care, consideration and love, this thesis would have been much harder.

First, I am grateful for the advice and support from my advisor Professor Carlos Lucena in the most difficult moments during the master course and thesis writing process. I would like also to thank very much Elder and Ingrid for their time, suggestions and critical remarks that were very helpful in the completion of this thesis.

I would like also to thank Professor Simone Barbosa, and the members of my committee, Professor Ivan Mathias Filho and Professor Gustavo Robichez de Carvalho, for taking time to read my thesis and giving constructive feedback.

A huge thanks to Charles for his love and support every day, giving me the energy and the understanding needed to go along with this thesis. Moreover, thank him for helping me with my English.

To Isela, for being always an unconditional friend and for her lot of wise advices.

To Alejandro, Aracelys, and Felix for their constant love and positive energies.

To Sofia for her friendship, cheer and making me laugh in the difficult moments.

To Rita for giving me much support in crucial moments during the master course and for introducing me to Marcelo Oikawa, who has gone out of his way to help me and is always cheerful.

To Jose for his advices.

To Chico Dantas, without him I would have not been in Brazil.

To the professors of Informatics Department and colleagues at Software Engineering Laboratory at Pontifical Catholic University of Rio de Janeiro, particularly to Soeli, for all the opportunities, their knowledge and friendship.

To CAPES for the financial aid granted.

To Nily for her friendship. 
Exclusively to my dear family, even very far away, they are always close in my heart. Thanks very much for the sacrifices made to give me a better future, for being ever-present and giving me unconditional support, encouragement and love. 


\section{Resumo}

Jimenez, Merlin Parra; Advisor. Lucena, Carlos José Pereira de. Repositório de Agentes baseado em Semântica. Rio de Janeiro, 2012. 94p. Dissertação de Mestrado - Departamento de Informática, Pontifícia Universidade Católica do Rio de Janeiro.

A adoção de abordagems de desenvolvimento orientada a agentes de software traz inúmeros benefícios, tais como o suporte à análise, ao projeto e a implementação de sistemas de software. Postulamos que um ambiente de desenvolvimento robusto para a construção de sistemas orientados a agentes de software será reforçado por meio de métodos avançados de reuso. O reuso na engenharia de software leva à redução de custos e tempo envolvidos no desenvolvimento dos projetos. Além disso, promove melhorias relacionadas à adatação a diferentes exigências e necessidades dos engenheiros de software, melhorando qualidade dos sistemas desenvolvidos. No entanto, a pesquisa relacionada ao reuso de agentes ainda é escassa. Consequentemente, o problema da organização e do armazenamento de artefatos orientados a agentes ainda não atende as necessidades dos engenheiros de software. Portanto, o processo de recuperação de agentes ainda é um importante desafio a ser superado na engenharia de software orientada a agentes. Neste contexto, esta dissertação propõe uma metodologia e um protótipo de repositório baseado em tecnologias da web semântica que suportam estratégias de reuso, fundamentais ao processo de desenvolvimento de sistemas orientados a agentes. A metodologia proposta inclui (i) um meta-modelo flexível para representar os agentes e as suas características comuns e variáveis. Tais características são modeladas por meio de uma ontologia e um modelo de características (em inglês feature model), (ii) uma taxonomia específica de domínio para classificar os agentes de acordo com o seu domínio de aplicação, (iii) uma taxonomia para classificar os diferentes tipos de agentes, (iv) um serviço de subscrição (RSS) para anunciar a atualização dos agentes associados a categorias específicas, (v) um sistema de recomendação, apoiado por a ontologia e as taxonomias propostas, que permite aos usuários descobrir agentes reutilizáveis inter-relacionados, e (vi) métodos avançados de busca e navegação. Finalmente, avaliamos o repositório construído. O resultado da nossa avaliação 
mostra que o método proposto promove uma melhoria em relação à relevância da recuperação dos artefatos orientados a agentes.

\section{Palavras-chave}

Reuso de agentes, componentes baseadas em agentes, artefatos orientados a agentes, repositório de agentes, recuperação de informação baseada em semântica, engenharia de software orientada a agentes. 


\section{Abstract}

Jimenez, Merlin Parra; Advisor. Lucena, Carlos José Pereira de. Semantic-based Repository of Agent Components. Rio de Janeiro, 2012. 94p. MSc Dissertation - Departamento de Informática, Pontifícia Universidade Católica do Rio de Janeiro.

The adoption of a software agent-oriented development approach brings a number of benefits such as the support of analyses, design and implementation of software systems. We posit that a robust development environment for the construction of agent-oriented software systems will be enhanced by advanced reuse methods. Reuse in software engineering leads to the reduction of cost and time involved for developing projects, improvement of software quality, and easy adaptation to different requirements and needs of software engineers. However, research addressing agent reuse is meager and does not tackle the problem of organizing and storing agent-oriented artifacts according to the software engineers' needs. Therefore, the agent retrieval process turns into an important challenge to be overcome in agent-oriented software engineering. In this context, this thesis proposes a methodology and a repository prototype based on semantic web technologies that supports reuse for developing agent systems. The proposed methodology includes (i) a flexible meta-model for representing the agents and their common and variable features, which are represented by means of ontology and feature model, (ii) a domain-specific taxonomy to classify agents according their application domain, (iii) a taxonomy to classify the different behaviors of agents, (iv) a subscription service, $R S S$, to announce updates to the agents that are associated to specific categories, (v) a recommendation system, supported by the ontology and the taxonomies, that allows end-users to discover reusable interrelated agents and learn new information or agents as needed, and (vi) enhanced search and browsing methods for agents. Finally, we evaluate the constructed repository. The outcome of this evaluation shows that the proposed reuse method is an improvement in terms of the relevance of retrieved agentoriented artifacts. 


\section{Keywords}

Software agent reuse, agent component, agent-oriented artifact, agent repository, semantic information retrieval, agent-oriented software engineering. 


\section{Table of Contents}

1 Introduction 16

1.1. Contributions 21

1.2. Outline 22

2 Background 24

2.1. Software Reuse, Software Repositories \& Agent Components 24

2.2. Recommendation System 25

2.3. Variability Model 27

2.4. Information Retrieval Model 28

2.4.1. Scoring, Term Weighting and the Vector Space Model 31

2.4.2. Navigation Model 33

2.5. Semantic Web 33

2.5.1. Ontology 33

2.5.2. Taxonomy 36

2.6. Subscription Service 36

3 Related Work $\quad 37$

3.1. Literature Review 37

3.2. Final Remarks 43

4 Description of the Repository 44

4.1. Architecture of the Repository 46

4.1.1. Agent Modeling $\quad 50$

4.1.2. Classifying Agent Components $\quad 57$

4.1.3. Indexing Agent Components $\quad 59$

4.1.4. Recommendation System 60

4.1.5. Semantic-based Search System 65

4.1.6. Subscription Service 68

4.2. A Usage Scenario $\quad 69$

5 Evaluation $\quad 71$

6 Description of the Tool Support 73 
6.1. Implementation

7 Final Remarks 82

7.1. Contributions and Limitations 82

7.2. Future Research Directions 84

8 References 86

A Ontology 91

B Questionnaire 93 


\section{List of Figures}

Figure 1: General Process of Development for Agent Reuse...................44

Figure 2: Overview of the Repository. .............................................. 47

Figure 3: Multi-Agent Architecture of the Repository..............................49

Figure 4: UML Class Diagram of the Repository. ……...........................50

Figure 5: Feature Model of an Agent Component. .................................52

Figure 6: Feature Model of a Book Buyer Agent. ....................................53

Figure 7: Ontology to Model an Agent Component. ................................54

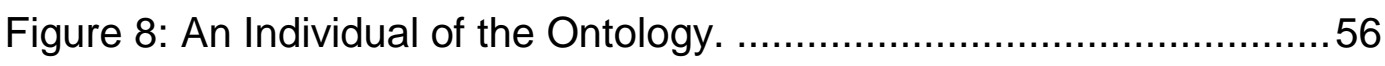

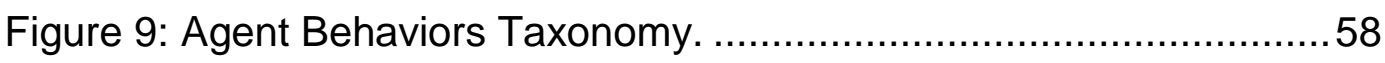

Figure 10: Application Domains Taxonomy.........................................59

Figure 11: Multi-Agent-based Recommendation System. ........................64

Figure 12: Multi-Agent-based Semantic Search.....................................68

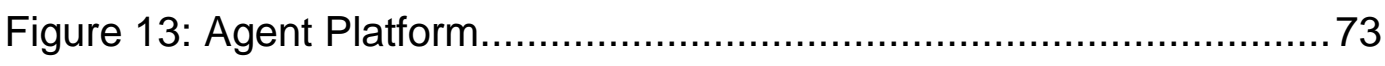

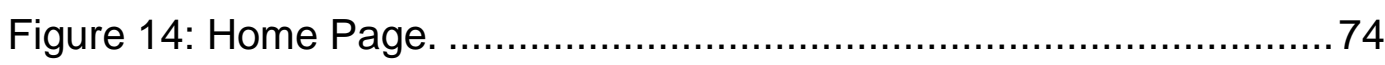

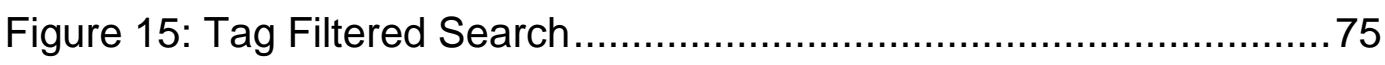

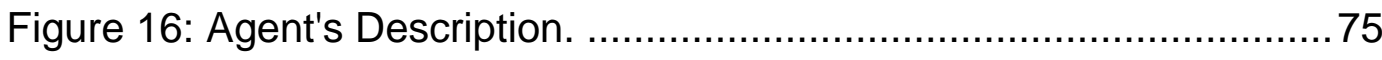

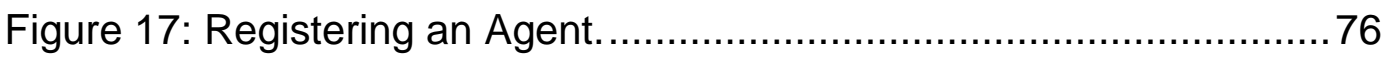

Figure 18: Adding Interfaces to the Agent. …………...........................

Figure 19: Adding Relationships to the Agent. ....................................78

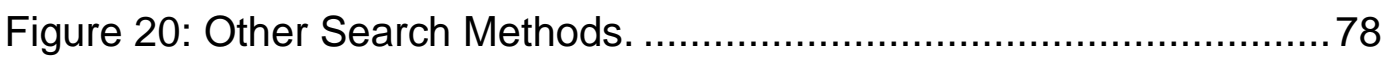

Figure 21: Subscription to Categories of Agents. ...................................79

Figure 22. Definition of Classes (i). .................................................. 91

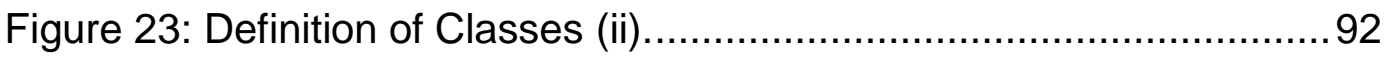

Figure 24: Individuals of the Attributes of an Agent. .............................92 


\section{List of Tables}

Table 1: Example of Related Agents. 62

Table 2: Evaluation Results. 72 


\section{Abbreviation and Acronym List}

AOSE Agent-oriented software engineering

CB Component-based

IR Information retrieval

RSS Really Simple Syndication

RSs Recommendation systems

RSSEs Recommendation systems for software engineering WWW World Wide Web 